\title{
Answering the Conventionalist Challenge to Natural Rights Theory
}

\section{Billy Christmas ${ }^{1}$ iD}

Published online: 29 July 2020

(c) The Author(s) 2020

\begin{abstract}
Ben Bryan argues that the strongest challenge to natural rights theory is to explain how it overcomes the Problem of Authority. Given that our natural rights are multiply realisable by a range of equally reasonable social conventions, how or why ought one particular realisation have authority? I argue that Thomistic and Kantian solutions to this problem do not count as solutions from natural rights theory, and therefore offer my own solution. When theories of natural rights describe the rights we have in terms that refer not only to moralised act-types, but rather, tell us which non-moralised acttypes ought to be moralised in the relevant way, they avoid the Problem of Authority altogether. Such theories of natural rights are singularly realisable at the level of regulative conventional rules, and only multiply realisable at the level of constitutive conventional rules. The latter form of multiple realisability does not raise the Problem of Authority.
\end{abstract}

Keywords Natural rights - Convention - Regulative rules · Constitutive rules · Property rights $\cdot$ Multiple realisability $\cdot$ Kantianism $\cdot$ Thomism

\section{Introduction}

Theorising about the structure and nature of natural rights is far from the most fashionable way of doing moral, political, and legal philosophy. Notwithstanding a 30-or-so-year foray following Robert Nozick's publication of Anarchy, State, and

Billy Christmas

wichristmas@gmail.com

1 Department of Political Economy, King's College London, Bush House, London WC2B 4BG, UK 
Utopia, ${ }^{1}$ theories of natural rights are not given much attention. Even contemporary libertarians tend not to engage with natural rights theory. ${ }^{2}$ Ben Bryan recently articulated a highly plausible reason to think this marginalisation might be justified. ${ }^{3}$ Bryan argues that natural rights theorists must, yet have hitherto failed to, answer what he calls the conventionalist challenge.

The realisation of our natural rights as actual constraints on our interpersonal relations will ultimately come in the form of social conventions of one form or another. In fact, in order to know what our natural rights amount to-what specific actions they permit, prohibit, and require us to engage in-we must look, in part, to convention. This draws into question both the ontological standing of natural rights as independent standards of moral evaluation of the conventions that regulate our interpersonal relations, and their moral import for the construction or critique of actual conventions. Bryan carefully works through the precise challenge these considerations may present to natural rights theories, and ultimately finds the residual challenge to be what he calls the Problem of Authority. Our natural rights are multiply realisable in conventions; the question is which particular realisations ought to have priority over the others. This threatens natural rights theory because one realisation taking priority over others gives those particular conventions moral authority. Such moral authority must be accounted for within natural rights theory, for its standing and relevance to be retained.

In this paper, I argue that two answers to the Problem of Authority that can be readily gleaned from literature, broadly from Thomistic and Kantian theories of rights, respectively, cannot provide the answer Bryan seeks. The former being an Aristotelian, common good-based solution to the question, and the latter a statist, Republican-based solution, do not count as answers from natural rights theory. I, however, offer a solution that does come from natural rights theory itself. Or rather, I show how natural rights theories can be formulated so as to avoid the Problem altogether. I argue that where natural rights theories describe natural rights in sufficient detail - in terms of how non-moralised act-types ought to be moralised-they are not multiply realisable in the way that gives rise to the Problem of Authority.

There are two levels at which social conventions that realise our natural rights exist - at the level of regulative rules and that of constitutive rules. Natural rights theories can, and sometimes are, stipulated in ways that do not give rise to multiple realisability at the level of regulative rules. All that remains then, is multiple realisability at the level of constitutive rules. However, constitutive rules define the particular act-types that natural rights theories moralise in various ways, and therefore such multiple realisability does not raise any moral problem, such as the Problem of Authority.

\footnotetext{
${ }^{1}$ Including the development of theories positively responsive to concerns of distributive justice; the socalled "left-libertarian" theories of natural rights. See Hillel Steiner, An Essay on Rights (Oxford: Blackwell, 1994) and Peter Vallentyne \& Hillel Steiner, eds. Left-Libertarianism and its Critics: the Contemporary Debate (New York: Palgrave Macmillan).

2 Jason Brennan, "Libertarianism After Nozick," Philosophy Compass, 13 (2018): cite page range.

${ }^{3}$ Ben Bryan, "The Conventionalist Challenge to Natural Rights," Social Theory and Practice, 43 (2017): 569-587.
} 


\section{The Conventionalist Challenge to Natural Rights}

Whilst our natural rights can be defined purely in the abstract, like anything abstract they cannot apply themselves on the concrete world. They do not have written into them exhaustive instructions of how they apply to particulars. ${ }^{4}$ In order for abstract theories of natural rights to be useful, they require agents to synthetically apply them on the world through some prior understanding of that concrete world. We need to know what counts as a person acting within her liberty to $x$, or as violating a person's claim to $y .^{5}$ Restatements of the theory that persons have the natural liberty to $x$ and natural duties to respect each other's claims to $y$ will not help us actually identify instances of these in the world. We have to be able to furnish the abstract concepts referred to by natural rights theories with worldly content, and thus apply those abstract concepts onto the world. ${ }^{6}$

The conventionalist challenge to natural rights theory is that the more we enquire as to what theories of natural rights say we may, must, and may not do in the concrete world, the more we end up looking to social conventions for answers. When we apply the abstract concepts referred in descriptions of our abstract rights, we must take assistance from actually-existing social conventions in order to know specifically what our rights amount to. As Bryan puts it:

The idea is not that we cannot give an abstract description of our rights without convention, but rather that we need convention in order to determine exactly what our rights require or permit us to do. ${ }^{7}$

The example Bryan gives of how we need to refer to social conventions in order to know what our natural rights amount to is the boundary problem. A theory of our natural right to private property could stipulate that we have a moral power to acquire ownership of extra-personal resources. It could stipulate the conditions under which this power may legitimately be exercised, and tell us the specific liberties, claims, duties, powers, liabilities, immunities, and disabilities we resultantly hold in rem in relation to that which we have acquired. And yet, when a person goes about acquiring property in the real world, the theory is unable to give the answers we need to know, specifically which actions we may, must, and may not engage in. Loren Lomasky writes the following.

\footnotetext{
4 As Wittgenstein noted, if they did, then would these instructions not be subject to further instruction as to how to apply them, and so on ad infinitum? There cannot be an infinite regress of rules of application, we must simply apply them by an act of judgment. (Ludwig Wittgenstein, Philosophical Investigations, trans. G. E. M. Anscombe (Oxford: Blackwell, 1958), §\$143-315).

5 I invoke the dominant Hohfeldian analysis of rights as being either liberties, claims, powers, or immunities, with correlative duties, liabilities, and disabilities in others (Wesley N. Hohfeld, "Fundamental Legal Conceptions as Applied in Judicial Reasoning," The Yale Law Journal, 26 (1917): 710-770.

6 This is, I believe, what Kant meant when he said, "[t]houghts without content are empty, intuitions without concepts are blind." (Immanuel Kant Critique of Pure of Reason, trans. P. Guyer \& A. W. Wood (Cambridge: Cambridge University Press, 1781 [1999]), A51/B76.

7 Bryan, "Conventionalist Challenge," 577.
} 
Suppose that A views from a mountaintop a vast expanse of virgin territory, rides around half of it, places boundary markers to set off a quarter of it, grazes his cattle over an eighth of it, fences in a sixteenth, clears a thirty-second, and plants a sixty-forth. How much of land that A first saw does he 'have'? When the morally minded B comes by, how much of the land should he feel obliged to acknowledge as belonging to A? If B eventually settles downstream from A, and A damns up the stream to create a pleasant lake for himself, have B's property rights been invaded?

There are no clear answers to these questions. Or, rather, there is no one best answer that can be deduced from the theory of basic rights. Persons will be unable to know and act on property rights that are ill-specified, and therefore it is requisite for the success of an order of rights that some determination be made. Social conventions are necessary to give concrete form to concepts such as appropriation, sale, bequest, and externality. ${ }^{8}$

As Bryan says, 'the whole point of natural rights [is] to provide moral constraints on the kinds of institutions human beings are permitted to set up'. ${ }^{9}$ So if it is the actually-existing social conventions regarding, for example, property acquisition, that ultimately determine what our moral rights with regard to property acquisition are, what work is the natural right to private property doing? This, Bryan refers to as the Problem of Constraint. ${ }^{10}$

The answer that Bryan gives himself is that a theory of natural rights constrains the range of social conventions that are potentially just around a more determinate core. The natural right to private property has fuzzy borders, but a non-fuzzy core, and the role that a natural right plays is in giving prima facie legitimacy to conventions that converge on that core. Going back to Lomasky's example, it seems that A certainly has a claim against B pulling up what he planted in the sixty-fourth portion of land in question, even if questions regarding the periphery must be settled by convention. So natural rights specify the non-fuzzy core, and conventions provide determinacy as to which border within the range of fuzziness we ought to opt for.

As natural rights theorists A. John Simmons and Eric Mack acknowledge, the actionable content of our natural rights is realisable by a range of different conventions, and the full details of what our natural rights give us a moral right to do is determined by the specific realisation that is manifested by actually-existing

\footnotetext{
${ }^{8}$ Loren Lomasky, Persons, Rights, and the Moral Community (Oxford: Oxford University Press, 1987), 131 Quoted in Bryan, Conventionalist Challenge, at 578-579. The boundary problem was also raised against the putative natural right to acquire private property by Hume and many others since (David Hume, Treatise of Human Nature. Reprinted in his The Philosophical Works of David Hume, vol. 2 (Edinburgh: Black \& Tait, 1738 [1826]), III.II.III.VIII; Robert Nozick, Anarchy, State, and Utopia (New York: Basic Books, (1974), 174-175; Geraint Parry, John Locke (London: George Allen \& Unwin, 1978), 52; Jeremy Waldron, “Two Worries About Mixing One's Labour," The Philosophical Quarterly, 33 (1983): 37-44, 42; A. John Simmons, The Lockean Theory of Rights (Princeton: Princeton University Press, 1992), 268).

9 Bryan, "Conventionalist Challenge," 581.

10 Ibid, 580.
} 
conventions. ${ }^{11}$ What natural rights say is that as a natural rights-holder, you have a right to acquire property in accordance with actually-existing conventions of property acquisition. If, say, the convention is that one acquired land by erecting a fence around it of at least one metre high, but when you acquire ownership, you do not acquire the power to transfer that ownership thereafter, the theories of natural rights (ones that say acquisition includes such powers of transfer) will tell us how this convention ought to be reformed. ${ }^{12}$ Alternatively, if the existing convention is that only members of some elite subset of society are permitted to acquire property, then the convention ought to be reformed so that all natural rights-holders may acquire property. If there are no conventions regarding property acquisition (or there is a convention that no acquisition of unowned extra-personal resource may take place), then natural rights theories tell us that there ought to be.

So natural rights theories still have actionable moral import insofar as they specify a range of social conventions that could realise them. Bryan rightly countenances the plausibility of this response to the Problem of Constraint, but also rightly notes that it raises a further problem: the Problem of Authority.

\section{The Problem of Authority}

The Problem of Authority is that if there is a range of social conventions that natural rights are realisable in, how do we know which realisation has authority over the others? It seems clear that there are better and worse realisations-indeed it is the residual moral import of natural rights to tell us which, as we saw just above. But there must be a range of realisations that are equally good in how they realise our natural rights, or if not equally good, incommensurable such that a move to another realisation would be an improvement along one particular metric of realisation, but worse along another one, with neither metric being reducible to the other. Why ought we adopt or comply with one set of social conventions rather than another, morally indistinguishable set?

Since social conventions are required in order to know what our natural rights amount to, the question of why we ought to adopt or comply with one convention rather than another has moral import for what our natural rights amount to. Most importantly, my natural right under one set of conventional definitions will entail a particular moral duty on your part, and yet under another set of conventionsperhaps one that you favour-will not entail that moral duty on your part, and this will mean I can have no correlating claim. It is important then that there be one coherent set of conventions morally selected, given the correlativity of claims and duties, powers and liabilities, etc. Which specific set of conventions has authority is

\footnotetext{
11 Simmons, The Lockean Theory of Rights, 104; 270; 316; Eric Mack, "Elbow Room for Rights," in Oxford Studies in Political Philosophy, vol. 1, ed. David Sobel, Peter Vallentyne, and Steven Wall (Oxford: Oxford University Press, 2015), 194-221.

12 And, of course, that reform is itself multiply realisable, because the precise ways in which the powers of transfer one acquires can be exercised is dependent on social conventions.
} 
a question of moral import, thus natural rights theory must provide a moral answer, or else show why the question does not relevantly arise.

Bryan does not assert that this challenge is insurmountable, he only claims that the burden is on natural rights theorists to overcome it. Social conventions just are social regulations of our conduct, so the conventionalist does not need to provide any answer to this question. They can say that we ought to comply with social conventions because questions of how we regulate our conduct just are questions of how our conduct is conventionally regulated. If the moral import of natural rights theory is to be salvaged, it must solve the Problem of Authority.

In the following section we will discuss three solutions to the problem. The first is a Thomistic answer that Bryan himself considers, but ultimately finds unconvincing in that it cannot count as an answer from natural rights theory itself. The second is a Kantian answer that I think ought to be rejected for similar reasons. The final one I believe effectively solves the Problem of Authority, and hence overcomes the conventionalist challenge to natural rights theory. It is not an answer to the question, but rather an account of the structure of natural rights that avoids the possibility of the question being raised.

\section{Two Possible Answers}

\section{The Thomistic Answer}

The answer Bryan considers comes from St Thomas Aquinas by way of John Finnis. Finnis argues that the actually-existing conventions (assuming them to be within the range of multiple realisability of natural rights) have authority over other possible realisations because they offer the greatest prospect of securing the common good of general coordination, without which none of us could secure our individual good, whatever it may be. ${ }^{13}$ Actually-existing social conventions, such as those enshrined in positive law, are, Finnis conjectures, the most salient, and hence the ones we can expect others to comply with. ${ }^{14}$ General compliance with the same conventions is itself to be valued in addition to the value of the natural rights those conventions realise.

Bryan responds that this does not count as an answer from natural rights theory. He argues that an essential component of natural rights theory is that the moral character of rights is independent of questions of the common good inasmuch as they set

\footnotetext{
13 John Finnis, Natural Law and Natural Rights, 2nd ed. (Oxford: Oxford University press, 2011), chaps. 9-11; "Law's Authority and Social Theory's Predicament," in Philosophy of Law: Collected Essays, vol. 4 (Oxford: Oxford University Press).

14 On the role of the salience of a norm in affecting its adoption, see Thomas Schelling, The Strategy of Conflict, new ed. (Cambridge: Harvard University Press, 1960 [1990]); David Lewis, Convention: A Philosophical Study (Oxford: Oxford University Press, 1969), 35-38; Cristina Bicchieri, The Grammar of Society: The Nature and Dynamics of Social Norms (Cambridge: Cambridge University Press, 2006); Norms in the Wild: How to Diagnose, Measure, and Change Social Norms (Oxford: Oxford University Press, 2016).
} 
side-constraints on our pursuit of both our own good and the common good. ${ }^{15}$ And therefore settling questions over the moral content of natural rights by appeal to the common good is too contrary to the essence of natural rights theory to count as a solution from natural rights theory. Finnis's general approach to natural rights is not one shared in the wider natural rights literature, for precisely this reason: rights are a protection against having to act in the general welfare.

\section{The Kantian Answer}

Kantians explicitly grapple with the Problem of Authority in their discussions of the nature of acquired rights. ${ }^{16}$ They argue that in a state of nature the actionable content of our acquired rights is indeterminate. Moreover, they argue that the imposition of one particular interpretation of our rights would itself be unjust. Given that there are multiple, equally reasonable interpretations of what our acquired rights amount to, for any one person to act upon one particular interpretation thereof would constitute a unilateral imposition of their will upon others, thereby violating those others' right to freedom by being subjected to the will of the enforcer. ${ }^{17}$ This is the particularly Kantian problem that arises from the Problem of Authority; giving any particular interpretation authority over others unavoidably means giving some particular person's interpretation authority, and to that extent presuming that she has some natural authority or moral superiority over others. ${ }^{18}$

15 “Conventionalist Challenge," 586; cf. Nozick, Anarchy, State, and Utopia, 28-35.

${ }^{16}$ Acquired rights are natural rights that we have as a result of taking some particular action, rather than as a result of merely existing. These are typically rights to external objects (property rights).

17 Whilst Kantians argue that the structure of a system of private property can be known a priori, they argue that the particular rights particular individuals have vis-à-vis particular actions and objects cannot. For example, see Arthur Ripstein, Force and Freedom: Kant's Legal and Political Philosophy (Cambridge: Harvard University Press, 2009), 86-87. As Martin Stone articulates it, "[m]orality might tell us a priori that we are bound to respect the boundaries of persons and property, but it affords us no way of deducing just what, in various circumstances, those proper boundaries are." ("Legal Positivism as an Idea About Morality," The University of Toronto Law Journal, 61 (2011): 313-341, 336.

${ }^{18}$ Advocacy for a versions of this argument can be found in Ernest J. Wienrib, The Idea of Private Law, rev. ed. (Oxford: Oxford University Press, 1994 [2012]) chap. 4; Jeremy Waldron, "Kant's Legal Positivism," Harvard Law Review, 109 (1996): 1535-1566; The Dignity of Legislation (Cambridge: Cambridge University Press, 1999), chap. 3; Katrin Flikschuh, "Freedom and Restraint in Kant's Metaphysical Elements of Justice," History of Political Thought, 20 (1999): 250-271; Kant and Modern Political Philosophy (Cambridge: Cambridge University Press, 2000) esp. chap. 4; "Reason, Right, and Revolution: Kant and Locke," Philosophy \& Public Affairs, 36 (2008): 375-404; Helga Varden, "Kant's Non-Voluntarist Conception of Political Obligations: Why Justice is Impossible in the State of Nature," Kantian Review, 13 (2008): 1-45; "Kant's Non Absolute Conception of Political Legitimacy-How Public Right "Concludes" Private Right in the "Doctrine of Right," Kantian-Studien, 101 (2010): 331-351; Alan Brudner, "Private Law and Kantian Right," University of Toronto Law Journal, 61 (2011): 279-311; Ripstein, Force and Freedom, chaps. 3, 6; "Kant and the Circumstances of Justice," in Kant's Political Theory: Interpretations and Applications, ed. E. Ellis (University Park: Pennsylvania University Press, 2012); Anna Stilz, Liberal Loyalty: Freedom, Obligation, and the State (Princeton: Princeton University Press, 2009), chap. 2; "Nations, States, and Territory," Ethics, 121 (2011): 572-601; "Why Does the State Matter Morally? Political Obligation and Particularity" in Varieties of Sovereignty and Citizenship, ed. Sigal R. Ben-Porath \& Rogers M. Smith (Philadelphia: University of Pennsylvania Press, 2012); "Provisional Rights and Non-State Peoples" in Kant and Colonialism: Historical and Critical Perspectives, ed. K. Flikschuh \& L. Ypi (Oxford: Oxford University Press, 2016); Louis-Philippe Hodgson, "Kant on 
The Kantian solution is to have an interpretation imposed on all that is not any particular person's private, unilateral interpretation and imposition, but rather a public, omnilateral interpretation and imposition. It is only the laws laid down by a state that can have authority without simultaneously privileging some persons' private interpretations of justice. Therefore, it is those conventions commanded by Leviathan that have authority in how natural rights are realised. ${ }^{19}$

Like the Thomist approach, this also does not count as an answer from natural rights theory because it is premised on the idea that the rights in question can only be made actual through the state. Anna Stilz, an important contemporary advocate and expositor of the Kantian view, says that our 'pre-existing, coercible duties to other people [...] we can fulfill only through states' ${ }^{20}$ Whilst these are moral rights of a sort-inasmuch as we have a natural duty to institute a state and comply with its laws, in part, for their sake - such rights cannot be said to be natural since we do not really have them in the state of nature. ${ }^{21}$ Indeed, Kantians say that our acquired rights in a state of nature are merely provisional-lacking content and enforceability. $^{22}$ We do not wrong each other when we take each other's (provisional) property

\section{Footnote 18 (continued)}

Property Rights and the State," Kantian Review, 15 (2010): 57-87; Japa Pallikkathayil, "Deriving Morality from Politics: Rethinking the Formula of Humanity," Ethics, 121 (2010): 116-147; Rafeeq Hasan, "The Provisionality of Property Rights in Kant's Doctrine of Right," Canadian Journal of Philosophy, 48 (2018): 850-876; Thomas Sinclair, "The Power of Public Positions: Official Roles in Kantian Legitimacy," in Oxford Studies in Political Philosophy, vol. 4, ed. D. Sobel \& P. Vallentyne (Oxford: Oxford University Press, 2018); J. P. Messina, "Kant's Provisionality Thesis," Kantian Review (forthcoming); cf. Immanuel Kant, The Metaphysics of Morals, trans. M. J. Gregor (Cambridge: Cambridge University Press, 1779 [1991]). For critique of this position see Billy Christmas "Against Kantian Statism," The Journal of Politics, forthcoming (2021).

19 It is not clear how simply stipulating that the state is a public institution rather than private overcomes the problem of privileging one person's interpretation of rights over others, given that the state is made up of persons of equal status as those who are subject to its laws (Keith Dowding, "Republican Freedom, Rights, and the Coalition Problem," Politics, Philosophy \& Economics, 10 (2011): 301-322; Thomas W. Simpson, "The Impossibility of Republican Freedom," Philosophy and Public Affairs, 45 (2017): 27-53). However, Thomas Sinclair offers some possible ways around this ("The Power of Public Positions: Official Roles in Kantian Legitimacy," in Oxford Studies in Political Philosophy, vol. 4 ed. David Sobel, Peter Vallentyne \& Steven Wall (Oxford: Oxford University Press, 2018)).

20 "Why Does the State Matter Morally?", 246, emphasis added. Also see her Liberal Loyalty, chap. 2. She attributes a similar idea to Hugo Grotius in her "Property Rights: Natural or Conventional?" in The Routledge Handbook of Libertarianism, ed. Jason Brennan, Bas van der Vossen \& David Schmidtz (New York: Routledge, 2018). For an argument against this use of Grotius, see Billy Christmas, "Hugo Grotius and the Mystery of Ownership," Raisons Politiques, 73 (2019): 21-38.

21 As Brudner puts it, "[t]o call them "natural rights,' it turns out, is to flatter them." ("Private Law and Kantian Right").

22 The dominant Kantian view is that external property rights are categorically different from bodily rights; and that the indeterminacy of property rights outside of a set of legal convention imposed by a state does not apply to bodily rights. Bodily rights are, contrarily, determinate and binding even outside of a state (Ripstein, Force and Freedom, chaps. 3, 6). However, Japa Pallikkathayil argues that bodily rights are also indeterminate in the same way as external property rights outside of a state ("Persons and Bodies," in Freedom and Force: Essays on Kant's Legal Philosophy, ed. S. Kisilevsky \& M. J. Stone (Oxford: Hart, 2017)). 
or break our (provisional) contracts in a state of nature, rather we 'do wrong in highest degree' by failing to institute a state that actualises our acquired rights. ${ }^{23}$

A theory of natural rights is supposed to stand as an independent source of moral evaluation of our social institutions, but on the Kantian view, what our 'natural' rights amount to is not existentially independent of those social institutions. Whilst our natural right to freedom exists outside of a state, the specific and concrete rights that actually tell us what we may, may not, and must do, are entirely dependent upon the legal conventions imposed by the state; so they cannot be an independent source of evaluation of the state's laws. ${ }^{24}$

\section{Avoiding the Problem}

The way in which I believe natural rights theory can overcome the challenge is not in giving a moral justification for the ultimately authoritative conventions that partially define our natural rights, but rather in showing that properly structured theories of natural rights do not raise the question in the first place. This can be achieved by first looking at the two general levels at which natural rights can be realised in social conventions. There are regulative rules and constitutive rules that together constitute conventional realisation of natural rights. What I will show is that natural rights properly formulated are not multiply realisable at the level of regulative rules - when they are described appropriately - but are at the level of constitutive rules. And most importantly, that multiple realisability at this level does not raise the Problem of Authority.

\section{Two Kinds of Rules}

Regulative rules are the conventionally enshrined rules that regulate activities that are existentially independent of them. ${ }^{25}$ For example, the social convention of queueing involves the regulative rule of standing at the back, meaning that the person before you has priority over you, and you in turn have priority over the next arrival. It subsists in our expectation that others will do it, that they expect us to do it, that it serves some end, and that we may be subject to sanctions if we do not comply. This rule regulates the activity of waiting for things on a time-interval output. ${ }^{26}$ We could all wait to have our coffee order taken without any regulative rule whatsoever. It would be chaotic and inefficient, but it would still count as waiting to order. Likewise, driving in Japan, the British Isles, and former British colonies bar

\footnotetext{
23 Kant, Metaphysics of Morals, VI.307.

24 Brudner, "Private Law and Kantian Right.".

25 John R. Searle. Speech Acts: An Essay in the Philosophy of Language (Cambridge: Cambridge University Press, 1969), 33-42; The Construction of Social Reality (New York: Simon \& Schuster, 1995), chap. 2.

${ }^{26}$ We also often queue for things that are not temporally scarce such as when we are waiting to get on the plane. In these instances, queueing serves the purpose of reducing the time taken for everyone to get the thing they are guaranteed, rather than rationing individual units by timed priority.
} 
those in North America, is regulated by the rule that you keep to the left-hand side of the road, and of oncoming traffic. This rule regulates the existentially independent activity of driving. One could drive on the other side of the road, or down the middle, or swerve, and this would still count as driving. What regulative rules regulate are existentially independent act-types. They make certain ways of engaging in those act-types normative for us - we feel we ought to do them in that way.

Constitutive rules, on the other hand, define the activities they apply to. Such activities, therefore, are not existentially independent of their constitutive rules, unlike the case of regulative rules. ${ }^{27}$ For example, there is a wide spread social convention of promising that involves the regulative rule that you do not break your promises. One could break a promise without that affecting the fact of whether or not one did in fact perform the act-type of 'making a promise'. However, this convention also involves the constitutive rule specifying what counts as performing that act-type. Promising is normally performed through some kind of performative utterance such as saying 'I promise...' before naming the thing one intends to oblige oneself to do. ${ }^{28}$ One cannot promise except by the ways stipulated by the constitutive rules. One cannot make a promise by driving to Oxford or eating a pizza. ${ }^{29}$ To promise wrongly is to fail to promise. Other examples of constitutive rules might be those of mathematics. The rule of addition constitutes what it means to add. Adding wrongly, for example writing down ' $1+2=4$ ', is to fail to add. One might think that what one was doing was adding, but one would be mistaken. Reports of one's private psychological state at the time of writing it are neither here nor there. ${ }^{30}$ One can wait to order coffee in a way that breaks the regulative rules, say by pushing in the queue, and yet still perform the act of waiting to order coffee. However, failing to comply with constitutive rules is to fail to perform the acts they define. ${ }^{31}$ Whether or not one obeys the regulative rules is subject to moral evaluation, whereas the question of whether or not to obey the constitutive rules for some act-type is parasitical on the question of whether or not to engage in that particular action whatsoever, since to obey the constitutive rules of the action just is to perform the action.

\footnotetext{
27 Searle, Speech Acts; The Construction of Social Reality, chap. 2.

28 J. L. Austin, How to Do Things with Words (Oxford: Clarendon, 1955 [1962]); Searle. Speech Acts, chap. 3; Kent Bach, "Performatives Are Statements Too," Philosophical Studies, 28 (1975): 229-236; G. E. M. Anscombe, "On the Source of the Authority of the State," in The Collected Philosophical Papers of G. E. M. Anscombe, vol. 3: Ethics, Religion and Politics (Oxford: Basil Blackwell, 1978 [1981]); David Bloor, Wittgenstein, Rules and Institutions (London: Routledge, 1997), chap. 3.

${ }^{29}$ Unless one had prior to that said "if I drive to Oxford or eat a pizza, then I thereby promise to...", but this still involves in engaging in the performative act-type defined in the constitutive rule for promising.

30 Wittgenstein, Philosophical Investigations, §202; Remarks on the Foundations of Mathematics, ed. V. H. von Wright, R. Rhees \& G. E. M. Anscombe. Oxford: Blackwell, 1978), VI.32.

31 In some cases, there is a porous boundary between regulative and constitutive rules. For example, if when people said "I promise to..." they began to consistently renege on their promise in a socially widespread way, those words would likely cease to actually perform a promise because social expectations which in part constitute the rule would break down. And other, perhaps costlier signals than the mere performative utterance, would effectively perform a promise (Anscombe, 1957; 84-87; Long, forthcoming, chap. 5). This nuance to the distinction between regulative and constitutive rules, however, does not jeopardise what I argue here.
} 
Regulative rules require a prior set of constitutive rules in order to define the acttypes they regulate. Once constitutive rules emerge in order to provide a definition of the relevant activities, regulative rules provide determinate guidance on courses of action. A regulative rule makes certain ways of engaging in activities normative for us. Where regulative rules are effectively conventionalised, we often feel we ought to comply with them. ${ }^{32}$ A description of a regulative rule will moralise particular ways of engaging in activities, activities which can be referred to in a nonmoralised way. For example, it will tell us that we ought to stand behind the person who got there before us when we are waiting to order coffee. The activity of standing behind the person who got there before us is perfectly understandable in a purely descriptive and non-moralised way. The regulative rule moralises it by saying that is what you ought to do under the relevant circumstances.

Theories of natural rights are, inter alia, theories of what regulative rules societies should adopt and comply with, or rather, which ones we are entitled and obligated to. The problem of authority arises because they can, seemingly, only specify ranges of regulative rules. Behaviour that complies with one set within the range can be significantly morally distinguishable from behaviour that complies with others such that if interacting agents behave as if respectively different sets were in place, they will violate each other's rights as viewed from the perspective of the respective realisations. The key, then, is to find a way for natural rights theories to be singularly realisable at the level of regulative rules.

\section{Rightly Formulating Natural Rights Theories}

When theories of natural rights describe the regulative rules we ought to have by reference to moralised act-types, they are multiply realisable in the way that gives rise to the Problem of Authority. However, when they describe the regulative rules we ought to have by reference only to non-moralised act-types - and insodoing, demand a certain moralisation thereof-they are not multiply realisable in the problematic way. This needs unpacking.

Acquisition is a moralised act-type because when someone acquires ownership over something, it has moral import: others are now under a duty to that person to exclude themselves from this property. In making something one's property, the acquirer creates a set of moral requirements of third parties' interaction with her visà-vis the objects and spaces that are now her property. Actual regulative rules conventionalised in actual societies will tell us how we may acquire hitherto unowned property. ${ }^{33}$ If a theory of natural rights says that everyone has a natural right to acquire property-with no reference to any non-moral act-type by which one has

\footnotetext{
32 Lewis, Convention, 97-100; Margaret Gilbert, "Game Theory and Convention," Synthese, 46 (1981):41-93; Andrei Marmour, “On Convention,” Synthese, 107 (1996): 349-371; Bicchieri, Grammar of Society; Norms in the Wild.

${ }^{33}$ Granted, there is very little of the face of the Earth that is not claimed or legally recognised as either private property, or some kind of state-owned or managed property. So, think of the means by which one might acquire vacant land from the government.
} 
a right to acquire property - then the only thing in the world the description of this right has to cling to is the existing regulative rules regarding acquisition. It tells us that whatever the actually-existing convention for acquisition is, you have a right to do that.

Take another example. The infliction of undue harm is a moralised act-type. ${ }^{34}$ When someone inflicts undue harm upon another person, we take it that they have acted wrongfully. The fact that the harm was undue implies it lacked justification under the existing regulative rules. If a theory of natural rights says that you have a right over your body such that you have a claim against the infliction of undue harm-with no reference to any range of non-moral act-types which are said by that theory to constitute that undue harm - then the only thing in the world the description of this right has to cling to is the existing regulative rules regarding bodily harm. ${ }^{35}$ It tells us that whatever the actually-existing conventions for when you may and may not inflict harm on other person's bodies, you have a right to that treatment. ${ }^{36}$

In both cases, the natural right in question is clearly multiply realisable because the way in which it describes the right makes it relative to existing or possible regulative rules, and may only weakly demand their reform, as discussed above. Since rights described this way are indeed multiply realisable at the level of regulative rules, theories that describe rights merely in this way are subject to the Problem of Authority. However, if theories describe rights that refer to non-moralised act-types, and thereby issues demands on how they be moralised in our regulative rules, they are no longer multiply realisable at the level of regulative rules. They will be multiply realisable at the level of constitutive rules, but this does not raise the Problem of Authority, as we will now see.

If a theory of natural rights says that each person has a natural right to acquire things through using them in her ongoing activities, then what it clings to in the world is the constitutive rules for what counts as an ongoing activity. This way, it overrides actually-existing regulative rules regarding acquisition and says this is how you acquire, by using hitherto unowned resources in an ongoing way. It does not cling to existing regulative rules by referring only to moralised act-types (acquisition), but by telling us how to moralise non-moralised act-types (ongoing use). If a theory of natural rights says that each person has a natural right against interferences with their bodies, then what it clings to in the world is the constitutive rules for what counts as interfering (which will be relative to whatever actions they are engaged in at the time at which interference putatively takes place). This way, it overrides actually-existing regulative rules regarding bodily integrity and says this is how you

\footnotetext{
34 Cf. Bryan, "Conventionalist Challenge," 755.

35 Similarly, Martin Stone notes the following:

'[T]he articulation of 'dueness,' being formally subject to conflicting claims, is necessarily mediated by, or structured in terms of, a principle of reasonable reciprocal forbearance; [...] what is reasonable in such reciprocal relations is, in principle, indeterminate." ("Legal Positivism as an Idea About Morality," The University of Toronto Law Journal, 61 (2011): 313-341, 336)

${ }^{36}$ Carmen Pavel is right, therefore, that if our natural rights are described so as to refer to existing regulative rules, then they have little content outside our actually instituting such rules ("A Legal Conventionalist Approach to Pollution," Law and Philosophy, 35 (2016): 337-363). However, it is not the case that natural rights must be formulated in such a way, as I will argue below.
} 
unduly harm other persons-by interfering with their bodies. It does not cling to existing regulative rules by referring only to moralised act-types (infliction of undue harm), but by telling us how to moralise non-moralised act-types (interference). ${ }^{37}$ A theory of natural rights should tell us what people are due, rather than delegating that moral work elsewhere.

Beyond telling us what our bodily rights amount to, and how it is that we acquire rights in external objects and spaces, a theory of natural rights may often make pronouncements on more second-order forms of activity. For example, theories typically countenance that one has a right that others not use one's property without one's consent. This right might be regarded as fairly foundational; however, it needs to be parasitical on other statements of rights found at prior level of the theory at hand. Let me illustrate with an example.

In order to know what this right amounts to, one needs to know how to identify one's property, and how to identify whether one has given consent or not. One identifies one's property by identifying those objects and spaces that one has engaged in the relevant act-type that the theory moralises as acquisition, or that one has received from the previous acquirer through an act of transfer. ${ }^{38}$ We then need to know what counts as transfer. Since an act of transfer alters juridical relations, it is a moralised act-type, and therefore the theory itself needs to tell us by which acts we achieve a transfer. Let us assume that the theory in question countenances that all property is transferred by the consent of the initial owner; we then look to the constitutive rules of what counts as an act of consent. The constitutive rules tell us how to consent to things; the theory of natural rights tells us, inter alia, what this consent does in certain contexts. Of course, to be a genuine act of consent it must not be coerced. So, we also need to be able to identify what coercion is in order to know whether consent has truly taken place, and hence whether a given use of a person's property was a rights-violation or not. There are two potentialities for this. If coercion is essentially moralised, then the theory of natural rights must tell us what actions count as coercion. If coercion is deemed to be non-moralised, then the theory of natural rights needs to tell us which forms of coercion falsify a prima facie instance of consent in the case of a putative property rights violation. There is debate over whether coercion is essentially moralised or not ${ }^{39}$-one which I cannot get into here. But what I intend to be demonstrating is that, wherever the filling in of

\footnotetext{
${ }^{37}$ Hence, if we have a natural right against aggressive uses of our property, we only need to know the constitutive rules that define what counts as aggression, in order to know what that right amounts to. We do not need to refer to regulative rules that tell us which aggression is permitted and which is not, in order to know what our natural right against aggression amounts to, pace Pavel ("A Legal Conventionalist Approach to Pollution," 347).

38 Any natural rights theory that makes use of the concept of property will also probably need to say how property is transferred - that is, which act-types ought to be morally regarded as altering our rights and duties vis-à-vis a previously acquired object or space (Nozick, Anarchy, State, and Utopia, 150-153). 39 For example, see Steiner, "Individual Liberty," Proceedings of the Aristotelian Society, 75 (19741975): 33-50; Ralf M. Bader "Moralising Liberty," Oxford Studies in Political Philosophy, vol. 4 ed. David Sobel, Peter Vallentyne \& Steven Wall (Oxford: Oxford University Press, 2018); "Moralised Conceptions of Liberty," in Oxford Handbook of Freedom, ed. D. Schmidtz \& C. E. Pavel (Oxford: Oxford University Press, 2018).
} 
a description of a natural right or correlative duty includes a moralised act-type, the theory of natural rights must itself hold the resources for determining which nonmoralised act-types constitute the moralised one. It must complete all outstanding moralising work so as not to leave open the Problem of Authority.

Sometimes there will be several steps to this, as in the case of establishing whether a property rights violation occurred, since we need to establish whether or not the putative tortfeasor actually had the owner's consent or not. For a theory of natural rights to avoid being subject to the Problem of Authority, its inclusion of moralised act-types in its description of rights that persons have must be surrogates for further statements of what non-moralised act types constitute those moralised types.

Above, we saw how this works with regard to consent. Allow me to give another example of how this might work with regard to nuisance. It has been widely acknowledged in the recent literature that to have a right over any given object or space that others totally abstain from making any physical use of whatsoever, is an implausible conception of what it means to own something, or have some kind of property right to it. ${ }^{40}$ Imagine that one's ownership of one's house means that no physical change, save for those caused by the natural operation of laws of the physics, can occur upon or within the physical limits of the house (delineated by spatio-temporal coordinates), except by one's own choice or consent. ${ }^{41}$ Another person merely breathing too close to the house and thereby imposing carbon dioxide molecules onto it would constitute a violation of this right. Indeed, her mere presence within unobstructed view of the house would reflect light onto it and thereby effect a physical change within the physical bounds of one's property without one's consent. Theorists of natural rights, if they countenance a right against non-consensual use of one's property, are eager to show that this use is not to be construed in the broadest possible way. If the use a person non-consensually makes of one's property falls short of a nuisance or a trespass, then it is not a rights violation-indeed, it is not a use in the relevant sense of constituting a rights violation when non-consensual. It may look, then, that we have terminated analysis in this case at a moralised acttype, meaning that the Problem of Authority once again arises. Which determination of which uses count as nuisances ought to be the one that furnishes the content of our duties? However, I think that a theory of natural rights can plausibly identify

\footnotetext{
${ }^{40}$ Peter Railton, "Locke, Stock, and Peril: Natural Property Rights, Pollution and Risk," inTo Breathe Freely: Risk, Consent, and Air, ed. M. Gibson (Totowa: Rowman \& Allanheld, 1985); David Friedman, The Machinery of Freedom: A Guide to Radical Capitalism, $2^{\text {nd }}$ ed. (LaSalle: Open Court, 1989), 168; Barbara Fried, "Left-Libertarianism: A Review Essay," Philosophy \& Public Affairs, 32 (2005): 66-92; David Sobel, "Backing Away From Libertarian Self-Ownership," Ethics, 123 (2012): 32-60; Matt Zwolinski, "Libertarianism and Pollution," Philosophy and Public Policy Quarterly, 32 (2014): 9-21, 10-12; Mack, "Elbow Room for Rights"; Nicola Mulkeen, "Rescuing Self-Ownership: Tackling the Pollution Problem," Critical Review of International Social and Political Philosophy, online first (2017); Billy Christmas, "A Reformulation of the Structure of A Set of Compossible Rights," The Philosophical Quarterly, 69 (2019): 221-234.

41 As Steiner et al. have suggested we should (An Essay on Rights, 39, fn. 44; Peter Vallentyne, Hillel Steiner \& Michael Otsuka, "Why Left-Libertarianism Is Not Incoherent, Indeterminate, or Irrelevant: A Reply to Fried," Philosophy \& Public Affairs, 33 (2005): 201-215, 205).
} 
non-moralised types of non-consensual use of another's property that ought to count as rights violations qua nuisances and those that should not. The words of Judge Bramwell are instructive in this instance.

Faced with a plaintiff seeking to enjoin his neighbour's use of a brick kiln due to the fumes that it imposed upon his property, Bramwell recognised that the use of a brick kiln for the purposes of building a house on the plaintiff's land was partand-parcel of what constitutes ordinary use of land. Therefore, the costs imposed upon the defendant had to simply be tolerated as the costs of living in proximity of other land owners. ${ }^{42}$ (Likewise if the plaintiff wanted to use his own land for similar activities, it would be incumbent upon the defendant to tolerate them.) Bramwell said the following:

There must be, then, some principle on which such cases must be excepted. It seems to me that that principle may be deduced from the character of these cases, and is this, viz., that those acts necessary for the common and ordinary use and occupation of land and houses may be done, if conveniently done, without submitting those who do them to an action... It is as much for the advantage of one owner as of another, for the very nuisance the one complains of, as the result of the ordinary use of his neighbour's land, he himself will create in the ordinary use of his own, and the reciprocal nuisances are of a comparatively trifling character. The convenience of such a rule may be indicated by calling it a rule of give and take, live and let live. ${ }^{43}$

The use that the defendant made of the plaintiff's property vis-à-vis imposing fumes upon it was of a 'trifling character' because it did not interfere with the plaintiff's ordinary use of his own property, which is what is ownership thereof, inter alia, gives him a right to. The firing of bricks, then, was something that the defendant had a right to do on his own land. In determining what counts as a nuisance and, a forteriori, a property rights violation, judges often consider whether the non-consensual use made of the property by a third party constituted an interference with ordinary 'use and enjoyment' by the property owner. ${ }^{44}$

What counts as the ordinary use of one's own property is contextual to the time (when bricks typically have to be fired onsite), place (in England where houses are made of bricks), and nature of the property in question (whether it is farmland, a river, a dwelling, etc.). However, it is not set by a regulative rule but by a constitutive rule. What it means to use farmland qua farmland; what does it means to enjoy the use of one's apartment, etc. are constitutive of those activities. Therefore, which uses a property right ought to protect and enjoin, and hence, which count as

\footnotetext{
42 Bamford v. Turnley (1862) 122 ER 25 Vol. 122.

43 Bamford v. Turnley, 33.

44 For example, also see Robinson v. Kilvert (1889) 41 Ch. D 88 Court of Appeal; Network Rail v. Morris (2004) EWCA Civ 172 Court of Appeal. I think that a similar reasoning took place in the American case of Hinman v. Pacific Air Transport, in which Judge Haney determined that flying over a person's property constitutes neither a trespass nor a nuisance, because it did not interfere with ordinary use of such property (Hinman v. Pacific Air Transport (1936) $9^{\text {th }}$ Cir. 84 F.2d 755).
} 
nuisances, can be determined by categorising non-moralised act-types into moralised ones via an observation of whether or not they are interfering with normal use.

It might be thought that non-moralised act-types such as interference or ordinary use are also indeterminate and hence give rise to the Problem of Authority. However, this is not the case. What counts as interference is whatever interrupts, derails, frustrates, or brings to an end to some other ongoing activity that bypasses that individual's personal control of that activity. ${ }^{45}$ If we know what constitutes a given activity, then we know what constitutes an interference in it. The ability to identify human activity $x$ presumes the ability to identify instances of not- $x{ }^{46}$ Given that what counts as a certain kind of act-type is constituted by conventional constitutive rules, we observe and ought to expect variation across cultural contexts. Ordinary use of rural land in mid-nineteenth-century England is differently constituted to ordinary use of the Ganges river in twenty-first-century Varanasi. ${ }^{47}$ The definition of what counts as a given act-type is socially fixed at a given time and place, but fixed it is.

Where our natural rights are, at bottom, specified in terms of the non-moralised act types we may, must, and must not engage in, they are not multiply realisable at the level of regulative rules. Rather, they stipulate the set of regulative rules that is morally demanding of our institutional and personal compliance. They are, of course, multiply realisable at the level of constitutive rules. In stipulating regulative rules, such natural rights theories will cling to actually-existing constitutive rules. This, however, does not raise the Problem of Authority.

Take the example of promising, again. Different societies or cultures have different constitutive rules for what constitutes the act-type to promise. The regulative rule that one keeps one's promise will look different in those different societies, because of their divergence on the ways in which they promise-which behaviours count as promising. However, the question of 'why may I not promise in some other way?' is not a question that calls for any moral answer. In order to engage in the moral act of promising and thereby take on a duty of delivery, one must engage in an action that actually achieves that, and constitutive rules just tell you what counts as engaging in that sort of action. It is simply instrumentally impossible, rather than somehow immoral, to make a promise by driving to Oxford or eating a pizza-that is not what constitutes a promise, and the regulative rules says you take on obligations to deliver by giving a promise, not by doing some other thing. Likewise, the question of 'why may I not acquire land by paying off a local councillor' is not a question that has any moral answer. It is not that you ought not acquire in this way, it is that you cannot because paying off a local councillor does not count as acquiring the land. One may be able to acquire legal rights to land this way, but according to the relevant

\footnotetext{
45 Judith Jarvis Thomson, The Realm of Rights (Cambridge: Harvard University Press, 1990), 53.

46 Peter Winch, The Idea of a Social Science and its Relation to Philosophy, $2^{\text {nd }}$ ed. (London: Routledge, 1990), 86-87.

47 It might by thought that the notion of ordinary, closely akin to that of normal, is value-laden. However, as Cristina Bicchieri illustrates in her analysis of social norms, our tendency to make the normal normative is a function of our social psychology falling victim to the naturalistic fallacy, rather than anything built into the semantics of what we refer to when we say "normal" (Grammar of Society, 43, 96).
} 
theory of natural rights, this legal right will not be a moral right, and hence others will not have moral duties towards you to respect it, and you will not have the moral power to enforce or transfer it. Constitutive rules determine what counts as a particular non-moralised act-type, so when theories of natural rights demand that certain of these act-types carry a certain moral status, they so carry that status. If the constitutive rules were to change, then the regulative rules demanded by natural rights would look different. But at any given time, in any given social context, what is demanded by natural rights is determinate, and hence the Problem of Authority does not need to arise.

\section{Conclusion}

In order for us to know what our natural rights amount to, we must refer to social conventions, namely, the rules constituting what counts as the act-types that are moralised by theories of natural rights. We do not, however, need to refer to actuallyexisting regulative rules. Since constitutive rules fix the referents of the act-types that natural rights refer to, there are not multiple, equally good applications of theories of natural rights in any given time and social context. Therefore, the question of why one equally good application has authority over the others does not arise.

This answer to the conventionalist challenge to natural rights theory, however, does place a burden upon natural rights theorists. Theories of natural rights, if they want to have determinate application in any given time and social context, and hence avert the Problem of Authority, must describe our natural rights in terms that make reference not merely to moralised act-types, such as acquisition, transfer, undue, etc., but tell us which non-moralised act-types morally ought to be regulated.

Open Access This article is licensed under a Creative Commons Attribution 4.0 International License, which permits use, sharing, adaptation, distribution and reproduction in any medium or format, as long as you give appropriate credit to the original author(s) and the source, provide a link to the Creative Commons licence, and indicate if changes were made. The images or other third party material in this article are included in the article's Creative Commons licence, unless indicated otherwise in a credit line to the material. If material is not included in the article's Creative Commons licence and your intended use is not permitted by statutory regulation or exceeds the permitted use, you will need to obtain permission directly from the copyright holder. To view a copy of this licence, visit http://creativecommons.org/licen ses/by/4.0/.

Publisher's Note Springer Nature remains neutral with regard to jurisdictional claims in published maps and institutional affiliations. 